\title{
PENDIDIKAN KARAKTER HINDU
}

\author{
Ni Wayan Gateri \\ Institut Agama Hindu Negeri Tampung Penyang Palangkaraya \\ bawiayahfda@gmail.com
}

\section{Riwayat Jurnal}

Artikel diterima $\quad: 8$ Juli 2019

Artikel direvisi : 25 Juli 2019

Artikel disetujui : 1 Agustus 2019

\begin{abstract}
Abstrak
Tujuan pembangunan di Indonesia untuk mewujudkan manusia Indonesia seutuhnya mengandung makna bahwa kepribadian manusia yang utuh dan integral meliputi berbagai dimensi individu, sosial, ketuhanan dan kesusilaan, yang dikaitkan dengan pendidikan terutama pendidikan formal, yang manusia-manusianya diharapkan memiliki kecerdasan intlektual, juga memiliki keserdasan spiritual, emosional, sosial dan berkarakter mulia. Pendidikan karakter tentu saja, bukan hanya tanggung jawab sekolah, pendidikan karakter merupakan tanggung jawab bersama yang menyentuh nilai dan kehidupan para anak muda, berawal dengan keluarga dan meluas dengan komunitas sradha, organisasi pemuda, bisnis, pemerintahan, dan bahkan pada media (Licona, 2012:4). Isi dari pendidikan karakter yang baik adalah kebaikan-kebaikan seperti kejujuran, keberanian, keadilan, dan kasih sayang. Adalah disposisi untuk berprilaku secara bermoral (Atmaja,2017:1). Pendidikan karaker sangat penting diberikan kepada peserta didik diberbagai jenjang pendidikan formal. Dalam pelaksanaanya pendidikan karakter dapat diberikan bersinergi dengan mata pelajaran tertentu atau diberikan berdiri sendiri, sebagai sebuah mata pelajaran. Pendidikan sebagai proses memanusiakan manusia menjadi wahana yang tepat dan strategis untuk menumbuhkembangkan nilai-nilai kemanusiaan sehingga terbentuknya manusia seutuhnya, sehingga memiliki perkembangan pribadi yang seimbang, selaras, dan harmonis, pada dimensi-dimensi kemanusiaan.Pendidikan karakter dalam pendidikan agama Hindu akan menghasilkan orang-orang yang jujur, bukan karena tidak ada kesempatan untuk korupsi atau karena ada hukum yang mengancam, melainkan karena hidup jujur adalah pilihan sadar mereka.Dalam Kitab Sarasamuscaya sloka 177 disebutkan tujuan mempelajari pustaka suci Weda adalah untuk mendapatkan ilmu pengetahuan untuk memperbaiki prilaku dan dan kebiasaan hidup. Jujur kita akui selaku umat manusia semuanya selain memiliki beberapa kelebihan, juga dari berbagai kekurangan, dan kekurangan kerap kali menjadi salah satu faktor munculnya prilaku yang bertentangan dengan nilai-nilai etika (tata susila). Ajaran Tri Kaya Parisudha sebagai salah satu aspek untuk menyelaraskan berpikir yang benar, berbuat yang benar dan berkata yang benar guna mewujudkan pribadi yang santun, cerdas, dan berkarakter mulia berdasarkan dharma.

Kata Kunci : Pendidikan Karakter, Hindu
\end{abstract}




\section{Pendahuluan}

Pendidikan Agama Hindu adalah tata nilai yang menjadi norma-norma agama Hindu yang telah tersurat secara jelas dan lengkap dalam kitab-kitab suci atau sastra-sastra agama Hindu. Normanorma agama Hindu akan dapat dipahami dan dapat dijadikan dasar pendidikan, untuk mengantarkan suatu sistem perubahan yang positif. Menuju pembentukan karakter-karakter mulia yang diharapkan.Karena pendidikan itu adalah menanamkan kebiasaan-kebiasaan yang baik dengan mengikuti perkembangan jiwa anak didik, bahkan juga perkembangan atau perubahan lingkungan, yang selalu menyertai perjalanan waktu yang sangat panjang. Dalam mengarungi kehidupan dalam perubahan. Hidup adalah perubahan yang menjadi hukum alamdari sekian banyaknya sistem nilai yang diajarkan dalam agama Hindu adalah kerja, yang dalam agama Hindu disebut dengan karma. Karma adalah kerja, perbuatan,kegiatan action, yang bersifat moral maupun pisik. Atau kejiwaan adalah aktivitas berpikir, menghayal, maupun merenung. Memandang kerja atau kegiatan pisik sebagai persembahan merupakan pandangan yang positif yang dapat dipertahankan konsepnya.Agar segala perbuatan kerja atau kegiatan kita mempunyai nilai positif bagi kehidupan umat manusia yang perlu diperhatikan terlebih dahulu adalah pola dasar yang dapat mempengaruhi sikap hidup dan tingkah laku kita yaitu karakter.

Karakter adalah watak atau sifat dasar terbentuk oleh sikap yang dibentuk oleh kepekaan hati (perasaan) (Singer,2015:3). Dan kecerdasan rasio/akal (pemikiran)manusia.karakter inilah yang mempengaruhi sifat manusia yang terwujud menjadi perbuatan atau karma yang bisa saja perbuatan baik atau perbuatan buruk yang berakibat sesuai dengan kualitas perbuatan itu tadi, perbuatan atau sikap tingkah laku itu dapat dalam bentuk ucapan atau kegiatan fisik, seperti yang disebutkan di atas bisa juga dalam bentuk pikiran. Karena pikiran perasaan selalu berhubungan dengan hal-hal yang bersifat abstak.Oleh karena itu dalam menjalani hidup ini ditengah-tengah masyarakat kita harus mempelajari sistem nilai yang berkembang di masyarakat. Nilai-nilai itu seperti nilai keagamaan, sosial, ekonomi, politik, adat istiadat, dengan memahami 
sikap seperti ini maka kita dapat menyesuaikan diri mengambil sikap hidup dan memposisikan diri dengan mengambil peran dengan sifat-sifat karakter yang positif sehingga kebahagiaan hidup tercapai.

Pendidikan karakter bermakna lebih dari pendidikan moral, karena bukan sekedar mengajarkan mana yang benar dan salah tetapi lebih dari itu, pendidikan karakter menanamkan kebiasaan tentang hal yang baik dan benar, sehingga siswa menjadi faham tentang mana yang baik dan salah, mampu merasakan nilai yang baik dan mau melakukannya, karakter itu erat kaitannya dengan tabit, atau kebiasaan yang terus menerus dilakukan.(Galus, 208:19). Karakter adalah upaya-upaya konkrit untuk menciptakan situasi yang kondusif yang memungkinkan anak manghayati nilai-nilai secara efektif berdasarkan pengalaman yang bersifat riil dan sekuen. Dalam bahasa faedagogiknya pendidikan karakter menjadikan siswa tahu moralitas dan membiasakannya secara praktis. Selain sekolah ada yang tidak kalah pentingnya keluarga, teman sebaya, dan media masa, agen-agen ini membentuk struktur sosial tersendiri namun selalu berkaitan dengan struktur sosial lainnya bersinergi secara fungsional guna mewujudkan tujuan bersama yakni karakter mulia. Pembentukan karakter mulia melibatkan sekolah dan keluarga harus saling melengkapi dan saling bekerjasama.

\section{Pembahasan}

\subsection{Membentuk Karakter Mulia Melalui Pendidikan Agama Hindu}

Karakter adalah berasal dari bahasa latin characteryang artinya watak, tabiat. Sifat-sifat kejiwaan, budhi pekerti, kepribadian dan akhlak. Karakter adalah sifat kejiwaan akhlak atau budhi pekerti yang menjadi ciri khas seseorang atau sekelompok orang. Karakter merupakan nilai-nilai prilaku manusia yang berhubungan dengan Tuhan, diri sendiri, sesama, lingkungan, dan bangsa, yang terwujud dalam pikiran, sikap, perasaan, perkataan, perbuatan berdasarkan normanorma agama. tata karma, hukum, budaya, dan adat-istiadat. Karakter dapat juga diartikan akhlak dan budhi pekerti sehingga karakter bangsa sama dengan akhlak bangsa atau budhi pekerti bangsa 
(Fitri, 2012:20). Pendidikan karakter merupakan suatu proses penuntun peserta didik menjadi manusia seutuhnya yang berkarakter mulia dalam hati. jiwa, raga, rasa dan karsa. Pendidikan karakter dapat dimaknai sebagai pendidikan nilai, pendidikan budi pekerti, pendidikan moral, pendidikan watak, yang bertujuan untuk mengembangkan kemampuan peserta didik untuk memberikan keputusan baik-buruk, memelihara yang baik dan mewujudkannya dalam kehidupan sehari-hari. Pendidikan karakter mempersyaratkan adanya pendidikan moral dan pendidikan nilai. Pendidikan moral menjadi agenda utama dalam pendidikan karakter sebab seseorang yang berkarakter adalah seorang individu yang mampu mengambil keputusan dan bertindak secara bebas dalam rangka pribadi maupun dalam komunitas masyarakat yang semakin mengkukuhkan keberadaan dirinya sebagai manusia yang bermoral (Albertus,2015:201).

Pentingnya pendidikan karakter sebenarnya telah berlangsung semenjak manusia ada yang saat itu pula proses pendidikan dalam pengertian yang lebih sederhana sudah berlangsung. Pendidikan
Karakter sering muncul kepermukaan saat kala fakta kehidupan menyajikan berbagai keganjilan prilaku manusia yang tidak diharapkan, seperti; kenakalan remaja, pelanggaran hukum, dan etika, prilaku anarkis, gemar menyebar berita hoaks, bahkan prilaku anti sosial, yang merupakan fakta kehidupan sosial yang kerap muncul dan meresahkan masyarakat. Peranan pendidikan formal sering kali dipertanyakan dan saat itu pula wacana pendidikan karakter dibicarakan secara intensif. Pandangan para tokoh kita bahwa ini adalah sebagai akibat dari lemahnya pendidikan akhlak mulia. budhi pekerti yang belum berhasil menanamkan kesadaran spiritualitas yang berpusat pada keimanan dan ketaqwaan terhadap Tuhan Yang maha Esa atau Ida Sang Hyang Widhi Wasa.

Kualitas generasi muda kita merupakan cerminan masa depan bangsa. Pada jaman sekarang ini maraknya sejumlah kasus amoral dikalangan para remaja kita semakin hari semakin menyedihkan mulai dari tawuran antar pelajar, mengkomsumsi narkoba dan obat-obatan terlarang, pornografi, pemerkosaan, dan sebagainya. Sehingga dunia pendidikan harus berperan dalam 
rangka untuk mendidik anak bangsa dalam rangka menyiapkan generasi muda masa depan bangsa yang berkualitas. Dengan demikian tujuan dari pendidikan pada dasarnya adalah untuk memperbaiki moral. Pendidikan karakter menekankan atas spiritual untuk membentuk pribadi yang baik. Pendidikan karakter adalah pendidikan moral karena bukan sekedar mengajarkan yang benar dan salah, tetapi lebih dari itu yakni pendidikan karakter menanamkan kebiasaan (habituation), tentang hal yang baik,sehingga siswa menjadi faham (domain kognetif) tentang mana yang baik dan salah, mampu merasakan(domin efektif), nilai yang baik dan mau melakukannya (domein psikomotorik). Aristoteles mengatakan karakter itu erat kaitannya dengan habit atau kebiasaan yang terus menerus dipraktekkan dilakukan (Atmaja,2017:29). Ini artinya mana karakter yang baik dan buruk atau mana karakter yang benar dan salah, hal ini tidak sekedar diwacanakan saja, tetapi berbentuk kebijakan pendidikan. Dengan cara kebijakan pendidikan karakterakan memiliki legitimasi yang kuat dan lebih memudahkan bagi seseorang untuk memahaminya dan menempatkan dirinya pada pendidikan karakter yang benar dan baik.

\subsection{Tujuan Pendidikan Karakter}

Tujuan pendidikan karakter adalah untuk membentuk karakter yang terwujud dalam kesatuan esensial antara subyek dengan prilaku dan sikap yang dimilikinya, Karakter merupakan pengualifikasikan pribadi seseorang yang memberikan kesatuan dan kekuatan terhadap keputusan yang diambilnya. Karakter adalah semacam identitas. Karakter Pendidikan karakter merupakan hak dan kewajiban setiap warga Negara dengan terbitnya Perpres No 87 Tahun 2017 tentang penguatan pendidikan karakter(Rohmat Mulyana Sapdi, 2018:3).Tujuan pendidikan karakter untuk meningkatkan mutu penyelenggaraan dan hasil pendidikan di sekolah yang mengarah pada pencapaian pembentukan karakter dan akhlak mulia peserta didik secara utuh, terpadu, dan seimbang sesuai standar kopetensi lulusan pada setiap satuan pendidikan. Melalui pendidikan karakter diharapkan peserta didik mampu secara mandiri meningkatkan dan menggunakan ilmu pengetahuannya untuk mengkaji, menanamkan serta memakai nilai-nilai 
karakter dan akhlak mulia sehingga dapat diwujudkan dalam pergaulan sehari-hari. Untuk itu diperlukan manajemen pendidikan yang tepat agar pelaksanaannya dapat dilakukan secara berkelanjutan serta mencakup seluruh aspek karakter bangsa secara utuh dan menyeluruh. Dengan demikian pendidikan karakter tersebut betul-betul dapat menyiapkan generasi muda yang beradab dan bermartabat.Implementasi pendidikan karakter menekankan pada keteladan, penciptaan lingkungan, pembiasaan, melalui berbagai tugas keilmuan dan kegiatan kondusif. Dengan demikian apa yang dilihat, didengar, dirasakan, dikerjakan oleh peserta didik dapat membentuk karakter mereka. Pendidikan adalah usaha sadar untuk membangkitkan kesadaran, kecerdasan dan mempertajam kemampuan untuk membedakan baik buruk, benar salah. Selanjutnya pendidikan adalah menanamkan kebiasaan-kebiasaan yang diinginkan oleh pendidikan itu sendiri, yang pada akhirnya menjadi kebiasaan hidup. Kebiasaan hidup itu akan tumbuh berkembang menjadi karakter atau kepribadian yang sulit untuk diubah lagi. Pendidikan atau lingkungan sangat berpengaruh dengan pembentukan karakter. Pendidikan mempunyai kekuatan tersendiri dalam pembentukan karakter seseorang.

Implikasi pendidikan karakter menekankan pada keteladan penciptaan lingkungan dan pembiasaan melalui tugas keilmuannya dalam kegiatan yang kondusif. Dengan demikian apa yang dilihat, didengar, dirasakan dan dikerjakan oleh peserta didik dapat membentuk karakter mereka. Selain menjadikan teladan dan pembiasaan sebagai metode utama. Penciptaan iklim, budaya, serta lingkungan yang kondusif sangat penting untuk membentuk karakterpeserta didik.Penciptaan lingkungan yang kondusif dapat dilakukandengan berbagai hal variasi metode sebagai berikut :penugasan, pembiasaan, pelatihan, pembelajaran, pengarahan, dan keteladanan(Mulyasa,2014:10). Dengan berbagai metode tersebut mempunyai pengaruh yang sangat besar dalam pembentukan karakter peserta didik. Pemberian tugas disertai dengan pemahaman akan dasar-dasar filosofis sehingga peserta didik akan mengerjakan berbagai tugas dengan kesadaran dan 
pemahaman, kepedulian dan komitmen yang tinggi.dalam kegiatan kepramukaan terdapat pendidikan kesederhanaan, kesetiakawanan, kemandirian, kecintaan, kepemimpinan, kedisiplinan dan kegigihan dalam berusaha. Pendidikan karakter tanpa identifikasi karakter akan hanya menjadi sebuah perjalanan panjang yang tiadak ada ujungnya. Organisasi manapun di dunia ini yang menaruh perhatian besar terhadap pendidikan karakter yang menjadikan pilar prilaku individu.Heritage Foundation merumuskan ada 9 tujuan pendidikan karakter , 1) cinta kepada Tuhan, 2) tanggung jawab, disiplin, mandiri,3) jujur. 4) hormat dan santun, 5)kasih sayang, peduli, kerja sama, 6)percaya diri, kreatif, kerja keras dan pantang menyerah, 7)keadilan dan kepemimpinan, 8)baik dan rendah hati, 9)toleransi, cinta damai dan persatuan. (Mulyasa,2014 :15).

\subsection{Pendidikan Karakter dalam Agama Hindu}

Pendidikan karakter harus berkelanjutan dan tak pernah berakhir, sebagai bagian terpaduuntuk menyiapkan generasi bangsa, yang yang disesuaikan dengn sosok manusia masa depan berakar pada filosofi dan nilai kultur religious bangsa Indonesia. Pendidikan karakter harus menumbuhkembangkan filosofi dan pengamalan atas keseluruhan karakter bangsa ini secara utuh dan menyeluruh. Karakter bangsa mengandung perekat budaya dan kultur yang harus terwujud dalam kesadaran kultul dan kecerdasan kultul pada setiap warga Negara. Pendidikan karakter memiliki makna lebih tinggi dari pada pendidikan moral, karena pendidikan karakter karakter tidak hanya berkaitan dengan masalah benar dan salah,tetapi bagaimana menanamkan pembiasaan dengan hal-hal yang baik dalam kehidupan, sehingga peserta didik memiliki kesadaran, kepekaan, dan pemahaman yang tinggi. serta kepedulian dan komitmen untuk menerapkan kebajikan dalam tindakan nyata melalui prilaku yang baik, jujur, ikhlas, bertanggung jawab hormat terhadap orang tua, dan nilai-nilai karakter mulia yang lainnya dalam kehidupan seharihari. Dengan demikian orang yang berkarakter merupakan sifat yang alami seseorang dalam merespon situasi secara bermoral yang diwujudk Pendidikan adalah proses seseorang dalam rangka mengembangkan kemampuannya, sikap, dan tingkah laku di dalam masyarakat 
tempat mereka berada. Pendidikan adalah proses sosial yang terjadi pada orang yang dihadapkan pada pengaruh lingkungan yang terpilih dan terkontrol (khususnya yang datang dari pendidikan formal, sehingga mereka dapat memperoleh perkembangan kemampuan sosial dan kemampuan individu yang oftimal, pendidikan dipengaruhi oleh lingkungan atas individu untuk menghasilkan perubahan-perubahan yang sifatnya permanen (tetap) dalam tingkah laku, pikiran, dan sikapnya.Pendidikan juga diartikan dalam bahasa agama disebut dengan Widya yang merupakan catatan dari kebijaksanaan, yang di dalamnya mengandung tentang kebenaran tertinggi. Weda mengajarkan tentang bagaimana cara untuk mencapai kemurnian hati. Pendidikan juga usaha untuk membangkitkan kecerdasan dan mempertajam kemampuan untuk membedakan yang baik dan buruk, benar dan salah (Singer,2002 :25).pendidikan itu untuk menanamkan kebiasaankebiasaan yang diinginkan oleh pendidikan itu sendiri yang pada akhirnya menjadi kebiasaan hidup dan tumbuh bekembang menjadi karakter atau kepribadian yang sulit untuk dirubah lagi.
Jadi pendidikan atau lingkungan sangat berpengaruh dengan pembentukan karakter.

Dalam Nitisatra disebutkan ; nora na mitramang lwihane, wara guna maruhur, nora'na catru manglewihane,geleng ana ri hati,nora 'na sih mahanglewihane,sihikang atanaya,nor'na cacti daiwa juga sakti, tan ana mamahen. artinya:

Tidak ada sahabat yang melebihi pengetahuan, yang mempunyai manfaat atau berfaedah sangat tinggi bagi kehidupan, tidak ada musuh yang berbahaya dari nafsu jahat yang tumbuh dalam hati, tidak ada cinta yang melebihi cinta orang tua kepada anakanaknya, merupakan sarana pendidikan yang efektif, tidak ada menyamai kekuatan kecuali nasib, karena kekuatan nasib tidak tertahan oleh siapapun (Singer,2017:28).

Dengan menyimak sloka di atas bahwa peranan pendidikan itu dalam rangka mewujudkan anak didik yang berkarakter atau berkepribadian yang sangat kuat, tidak mudah dipengaruhi oleh hal-hal yang bersifat material. Karakter mulia yang melandasinya sifatsifat seseorang akan tercermin dalam tingkah laku sehari-hari. Tingkah laku tersebut akan terlihat dan dapat diamati dari tiga hal seperti sabda, bayu dan idep. Idep terimplementasi dalam pikiran 
merupakan sumber dari bentuk-bentuk pikiran itu sendiri yang diikuti oleh ucapan-ucapan, kata-kata dan perbuatan. Untuk menyeimbangkan pikiran, perkataan dan perbuatan kita maka kita harus mawas diri, introspeksi diri, mulat sarira yang bertujuan untuk memperoleh kedamaian. Karena kedamaian adalah dambaan bagi semua orang, kedamaian kebahagiaan utama, kebahagiaan tanpa kedamaian tidak akan ada. Karakter manusia sangatlah besar. Kedamaian dapat dicapai tergantung dari karakter kecakapan hati dan pandangan hidup atau pemikiran manusia itu sendiri. Ajaran Tri Kaya Parisudha sebagai landasan pembentukan karakter yang sangat dominan sebab salah satu tata nilai yang merupakan tata susila Hindu. Tri Kaya Parisudha yang cukup penting dalam implementasinya dalam seluruh kehidupan masyarakat, agar tercapainya keharmonisan dalam kehidupan masyarakat, untuk tercapainya keberhasilan pendidikan dan penanaman konsep pembentukan pendidikan karakter, yang diperlukan sistem kedisiplinan yang tinggi.

Pendidikan karakter adalah proses internalisasi budaya ke dalam diri seseorang dan masyarakat sehingga membuat orang beradab. Pendidikan bukan saja sebagai sarana transper ilmu pengetahuan, lebih luas sebagai sarana pembudayaan dan penyaluran nilai (enkulturisasi dan sosialisasi). Anak didik agar mendapatkan pendidikan yang menyentuh dimensi dasar kemanusiaan. Dimensi kemanusiaan mencakup tiga hal yaitu (1) afektif yang tercermin dalam kualitas keimanan,ketakwaan, akhlak mulia, termasuk budhi pekerti, yang luhur, serta kepribadian yang unggul, dan kompensi estetis.(2) kognitif yang tercermin dalam kapasitas piker dan daya intlektualitas untuk menggali dan mengembangkan serta menguasai ilmu pengetahuan dan teknologi.(3) psikomotorik yang tercermin dalam kemampuan mengembangkan ketrampilan teknis, kecakapan praktis, dan kompetensi kinestetis. Pendidikan karakter menjadi bagian yang paling berharga di dalam kehidupan manusia.aspek utama pendidikan karakter merujuk pada kualitas instinsik seperti kejujuran, kebaikan hati, ketenangan, kesetiaan, industri dalam artian bentuk kerja keras, aktif dan integitas (Julian dan Jhon, 2008:115). Pendidikan karakter 
adalah suatu sistem pemahaman nilainilai pendidikan karakter kepada anak didik yang meliputi komponen pengetahuan, kesadaran, atau kemauan dan tindakan untuk melaksanakan nilainilai tersebut. Akhirnya penulis berharap semoga tulisan ini dapat memberikan sumbangan pemikiran wawasan dan pmahaman para pembaca yang budiman dalam rangka membangun karater bangsa dan membantu para pendidik dalam melaksanakan pendidikan karakter secara tepat dan efektif.

\section{Penutup}

Keluarga merupakan tempat pendidikan pertama dan utama bagi seseorang. Pendidikan dalam keluarga sangat berperan dalam mengembangkan watak, kepribadian, nilai-nilai budaya, nilai-nilai keagamaan, dan moral, serta ketrampilan sederhana. hal ini untuk membimbing anak agar menjadi manusia yang beriman, bertakwa terhadap Tuhan Yang Maha Esa, tangguh, mandiri, kreatif, inovatif, beretos kerja, setia kawan, berakhlak mulia, peduli dengan lingkungan dan sebagainya. Peran orang tua dalam membentuk karakter dan kepribadian anak sangat penting. Dengan cara mengajarkan berbahasa dalam pergaulan sehari-hari pada anaknya. Keluarga berperan sebagai pondasi dasar untuk memulai pendidikan karakter melalui pembiasaan sikap, dan berprilaku sesuai dengan karakter yang diharapkan. Pembiasaan yang dimulai dengan keteladan dan diperkuat dengan penanaman nilai-nilai yang mendasari secara bertahap akan membentuk budaya serta mengembangkan hubungannya dengan Tuhan. Dengan lingkungan keluarga dapat menjadikan pula penting dalam pembudayaan karakter bangsa bagi anak dan generasi muda.

Dalam kehidupan sehari-hari dilingkungan kesatuan pendidikan perlu diterapkan totalitas pendidikan dengan mengandalkan keteladanan, penciptaan lingkungan dan pembiasaan hal-hal yang baik melalui berbagai tugas dan kegiatan. Pada dasarnya lingkungan pada satuan pendidikan dapat dilaksanakan sebagai berikut: penugasan, pembiasaan, pelatihan, pengajaran, pengarahan, serta keteladanan. Semuanya ini mempunyai pengaruh yang kuat dalam pendidikan karakter.setiap kegiatan mengandung unsur-unsur pendidikan seperti halnya kegiatan Pramuka, yang mengandung pendidikan kesederhanaan, kemandirian 
kesetiakawanan, kecintaan pada lingkungan,kepemimpinan dan kebersamaan. Langkah pertama dalam mengaplikasikan pendidikan karakter dalam satuan pendidikan adalah menciptakan suasana atau iklim satuan pendidikan yang berkarakter yang akan membantu transformasi pendidik, peserta didik, dan tenaga kependidikan menjdi warga pendidikan yang berkarakter.(Mulyasa,2014:274/275).

Untuk mewujudkan manusia berkarakter mulia harus mulai dari pikiran agar perkataan dan perbuatan yang menyertainya menjadi benar dan baik. Karakter merupakan tabiat yang menjadi ciri khusus dan sikap tingkah laku seseorang serta kekhasannya yang bersifat kejiwaan yang memembedakan seseorang dengan orang lain oleh karena itu karakter merupakan cirri-ciri yang bersifat psikologis akan tercermin dalam kegiatan hidup sehari-hari yang diharapkan tertanam pada setiap orang anak didik karena melibatkan pendidk. Ajaran Tri kaya parisudha menjadi acuannya dalam usaha untuk mencapai tujuan hidupnya yaitu kebahagiaan lahir dan bhatin, dalam kaitannya dengan tulisan ini watak yang berhubungan dengan penanaman dengan pendidikan. Proses pengembangan kepribadian ini meliputi latihan diri, dan disiplin moral, penyucian bhatin, menjalankan kehidupan dengan penuh kasih sayang selalu selaras dengan lingkungan, nengutamakan kerja sebagai swadharma tanpa pamrih.

Kalau kehidupan ini dapat ditempuh dengan karakter atau kepribadian seperti karma yang tertanam akan menumbuhkan hasil yang membahagiakan. Sebab manusia adalah pencipta nasibnya sendiri, saat ini dan dimasa mendatang. Oleh sebab itu pembentukan karakter atau kepribadiaan menjadi sangat penting agar perbuatan manusia untuk mengantarkan karmanya yang baik untuk dinikmatinya. Karakter adalah perpaduan tabiat manusia yang bersifat tetap sehingga menjadi tanda yang khusus untuk membedakan orang satu dengan yang lainnya. Pembentukan karakter suatu bangsa berproses secara dinamis sebagai fenomena sosio ekologis. Karakter merupakan jati diri, kepribadian, watak, yang melekat pada diri seseorang. Karakter tersebut dapat diciptakan dibentuk melalui proses pendidikan Agama Hindu serta pengaruh lingkungan masyarakat dimana manusia itu hidup. 
Namun watak seseorang juga watak bawaan, namun watak bawaan ini lebih banyak dipengaruhi oleh pendidikan dan lingkungan sehingga akan mengalami perubahan sesuai dengan arahan dari pendidikan yaitu membentuk karakter mulia seperti kejujuran, suka menolong, berbhakti kepada orang tua, teguh dalam keyakinan terhadap Ida Sang Hyang Widhi Wasa, taat kepada ajaran dharma, suka bekerja keras, selalu tenang dalam penampilan, tidak emosional, penuh dengan kesabaran, ramah, lemah lembut bicaranya. Orang seperti ini adalah orang yang berkarakter atau berwatak mulia, karena tingkah laku, sikap serta perbuatannya memenuhi kaedah-kaedah ajaran agama Hindu khususnya ajaran Tri Kaya parisudha dan tata susila (etika).Karakter itu ada dua kondisi yaitu berasal dari bawaan dan yang kedua dibentuk dari proses pendidikan, baik secara formal maupun non formal, pengaruh lingkungan, pergaulan sosial kemasyarakatan.Agar keberadaan kita sebagai mahluk Tuhan dapat secara maksimal mengabdikan diri dalam masyarakat dengan karakter yang kuat kita menjadi teladan di tengah-tengah masyarakat itu sendiri, kita tidak boleh kehilangan jati diri, hidup kita akan goyah, menurut Thomas Woodrow (dalam Nasution,2012:X) berpesan kepada kita sebagai berikut: ketika kamu kehilangan kekayaan hal ini adalah hal kecil, ketika kamu kehilangan kesehatan, kamu kehilangan sesuatu, ketika kamu kehilangan karakter, kamu telah kehilangan segalanya. Demikianlah betapa pentingnya pembentukan karakter, dan karakter itu merupakan suatu sistem nilai yang menjadi kekuatan dalam mengarungi samudra kehidupan ini. Shantih.

\section{Daftar Pustaka}

Ali,H Mhamad.1992.Guru Dalam Proses Belajar Mengajar.Bandung : Sinar Baru.

Arifin. Zainal,RS. 2011.Konsep dan Model Pengembangan Kurikulum.Bandung : PT. Remaja Rosdakarya.

Atmaja, Bawa. 2017.Agama Hindu, Pancasila, dan Kearifan Lokal Fondasai Pendidikan Karakter. UNDIKSA : Pustaka Larasan

Isna, Nurla. 2012.Mencetak Karakter Anak Sejak Janin. Jogjakarta :Diva Press.

Koesoema.

Albertus Doni.2015.Pendidikan Karakter. Strategi Mendidik Anak di Jaman Global. Jakarta : PT. Gramedia

Lickona. Thomas.2013.Mendidik Untuk Membentuk Karakter. Bagamana 
Sekolah Dapat Memberikan Pendidikan tentang Sikap Hormat dan Bertanggung Jawab.Jakarta : Bumi Aksara.

Mas.Raka, Gede AA.2004.Membangun Masyarakat Berkwalitas Melalui Kepedulian PadaTata Susila dan Budhi Pekerti Hindu(Sebuah Studi Dalam Rangka Mengantisipasi Pasca Bom Di Obyek Pariwisata Legian Kuta Denpasar Bali).Surabaya : Paramita

Mulyasa. H.E.2005.Manajemen Pendidikan Karakter.Jakarta: Bumi Aksara.

Muslick, Masnur. 2014. Pendidikan Karakter.Menjawab Tantangan Krisis Multidimemsional. Jakarta :Bumi Aksara.

Rohman, Arif. 2012.Kebijkan Pendidikan.Yogyakarta: Aswaja Pressindo

Sagala, Syaiful H. Kemampuan Profesional Guru Dan Tenaga Kependidikan. Bandung : Alfabeta.

Samba, IGede.2016.Mengenal Hindu. Sebagai Satu Budaya Sikap Dan Prilaku Hidup. Bandung : Yayasan Rurung Indonesia.

Santosa, Iman Budhi.2008.Budi Pekerti Bangsa. Yogyakarta : Arti Bumi Intaran.

Singer, I Wayan.2015.Pendidikan Karakter Berlandaskan Tri Kaya Parisudha. Denpasar: Pustaka Manikgeni.

Soemanto, Wasty.1998.Psykologi Pendidikan. Jakarta:Rineka Cipta

Sukmadinata, Nana Syaodih. Pengembangan Kurikulum Teori dan Prakteknya. Bandung : PT Remaja Rosdakarya.
Sutrisno, H, Suyadi.2016.Desain Kurikulum Perguruan Tinggi. Mengacu Kerangka Kualifikasi Nasional Indinesia.Bandung : PT Remaja Rosdakarya.

Tim Penyusun.2009.Undang-Undang Guru dan Dosen.Bandung :Fokus Media.

Zubaedi.2011.Desain Pendidikan

Karakter. Konsepsi dan aplikasinya dalam Pendidikan. Jakarta: Kencana Prenada Media Grup.

Zuriah, Nurul.2008.Pendidikan Moral \& Budhi Pekerti Dalam Persepektif Perubahan.Jakarta : PT Bumi Aksara. 